\title{
Pengaruh Media Promosi Kesehatan tentang ASI Eksklusif terhadap Peningkatan Pengetahuan Ibu di Wilayah Kerja Puskesmas Lubuk Begalung Padang Tahun 2014
}

\author{
Binarni Suhertusi ${ }^{1}$, Desmiwarti ${ }^{2}$, Emi Nurjasmi ${ }^{3}$
}

\begin{abstract}
Abstrak
Upaya meningkatkan cakupan pemberian ASI eksklusif sudah banyak dilakukan, diantaranya dalam bentuk promosi kesehatan. Namun demikian hingga saat ini kegiatan tersebut belum menunjukkan hasil yang optimal terutama dalam hal penggunaan media. Tujuan penelitian ini adalah untuk mengetahui pengaruh media promosi kesehatan terhadap peningkatan pengetahuan menggunakan media leaflet dan media film. Ini merupakan penelitian eksperimen semu (quasi-experimental) dengan rancangan pretest-posttest group design. Dilaksanakan di wilayah kerja puskesmas Lubuk Begalung Padang tahun 2014. Subjek penelitian adalah ibu hamil sebanyak 42 orang yang dipilih dengan cara simple random sampling. Subjek dibagi menjadi dua kelompok, kelompok pertama menggunakan media leaflet dan kelompok kedua dengan media film. Data dianalisis dengan uji Wilcoxon Signed Rank Test untuk mengetahui perbedaan pengetahuan sebelum dan sesudah promosi kesehatan dan uji Mann-Whitney membandingkan kedua media promosi kesehatan. Rata-rata pengetahuan responden sebelum diberikan promosi kesehatan dengan media leaflet 8,71 dan setelahnya 11,52. Pada media film sebelum diberikan promosi kesehatan 7,90 dan setelahnya 13,19 . Selisih nilai pengetahuan responden dengan media leaflet 2,81 dan media film 5,29. Ada peningkatan pengetahuan ibu sebelum dan sesudah diberi promosi kesehatan dengan media leaflet dan media film. Media film lebih efektif meningkatkan pengetahuan dibanding dengan media leaflet.
\end{abstract}

Kata kunci: ASI eksklusif, leaflet, film

\begin{abstract}
Various attempts have been taken to improve the granting of exclusive breastfeeding, one of them is health promotion. Nonetheless, the health promotion has not shown the optimal result especially on the use of media. The objective of this study was to determine the effect of health promotion regarding exclusive breastfeeding on the knowledge improvement of pregnant mothers either by using leaflet or film media. This was a quasi-experimental study with pretest-posttest group design. This study was conducted in the area of Lubuk Begalung health center Padang in 2014. The subjects were 42 pregnant women, choosen by using simple random sampling. The subject were divided into two categories. The first category was given a health promotion by using leaflet as the media and the second category was given by using film as the media. The data analyzed by using Wilcoxon Signed Rank Test to compare the knowledge of respondent before and after being given promotion and Mann-Whitney test to compare both of media. The average of respondent knowledge before being given health promotion by using leaflet was 8.71 and after being given health promotion was 11.52. In media film, the average of knowledge before was 7.90 and after was 13.19. The deviation of knowledge value of leaflet was 2.81 and film was 5.29. There is a significant knowledge improvement before and after being given the health promotion either by leaflet or film. Film is more effective in improving the knowledge of pregnant mothers compare than leaflet.
\end{abstract}

Keywords:Exclusive Breastfeeding, leaflet, film 
Affiliasi penulis: 1. Program Studi Magister Kebidanan FK UNAND (Fakultas Kedokteran Universitas Andalas Padang). 2. Bagian Kebidanan FK UNAND/ RSUP dr. M. Djamil Padang. 3. Poltekkes Kemenkes Jakarta 3

Korespondensi : Binarni Suhertusi, Jl. Bandes No.6 RT 05 RW 05 Rawang Kec. Padang Selatan-Padang, E-mail:

suhertusibinarni@yahoo.com, Telp: 08126729035

\section{PENDAHULUAN}

Pemberian Air Susu Ibu (ASI) merupakan cara pemberian makanan atau susu terbaik dan paling tepat untuk meningkatkan kualitas SDM pada saat awal pertumbuhannya, karena ASI mengandung berbagai nutrien yang diperlukan untuk tumbuh kembang bayi secara umum maupun tumbuh kembang berbagai organ secara khusus. Disamping itu ASI mengandung zat antibodi yang dapat melindungi bayi terhadap penyakit dan kematian akibat penyakit infeksi yang umum ditemui pada tahun pertama kehidupan. ${ }^{1}$

Tahun 2010 persentase bayi yang menyusui eksklusif sampai dengan usia 5 bulan hanya 15,3\%. Sebanyak $43,6 \%$ bayi sudah diberikan makanan prelakteal (makanan atau minuman yang diberikan kepada bayi baru lahir sebelum ASI keluar). Tahun 2012hanya $27,1 \%$ bayi umur $4-5$ bulan yang mendapat ASI eksklusif. ${ }^{2,3}$

Cakupan pemberian ASI eksklusif di Sumar tahun 2011 (48,7\%) dan tahun 2012 (61,2\%). Di kota Padang pencapaian ASI eksklusif dua tahun terakhir yaitu 75,3\% (2011) dan menurun menjadi 62,4\% (2012). Rendahnya pencapaian tersebut tidak terlepas dari rendahnya pencapaian di setiap puskesmas. Dari 20 puskesmas yang ada, ternyata puskesmas Lubuk Begalung menduduki peringkat terendah dibanding dengan puskesmas lainnya yaitu tetap pada angka $48,8 \%$ untuk dua tahun terakhir ini. Data tersebut menunjukkan bahwa cakupan pemberian ASI eksklusif masih dibawah Standar Pelayanan Minimal (SPM) Nasional yaitu $80 \%$. $^{4,5,6,7}$

Salah satu upaya untuk meningkatkan cakupan pemberian ASI eksklusif adalah dengan promosi kesehatan.Promosi kesehatan tidak hanya menyadarkan masyarakat atau meningkatkan pengetahuan masyarakat tentang kesehatan tetapi terdapat usaha untuk memfasilitasinya dengan tujuan perubahan perilaku masyarakat. ${ }^{8}$ Penelitian yang dilakukan Emilia menunjukkan, bahwa terdapat pengaruh yang signifikan antara pengetahuan dan sikap ibu terhadap pemberian ASI eksklusif dengan media poster dan leaflet. $^{9}$

Proses peningkatan pengetahuan tidak lepas dari media promosi kesehatan yang digunakan. Penelitian ini menitikberatkan pada penggunaan media leaflet dan film dalam meningkatkan pengetahuan ibu tentang ASI eksklusif. Leaflet merupakan media yang paling sering digunakan dalam berbagai pendidikan kesehatan, sedangkan media film merupakan media yang mudah dipahami dan lebih menarik perhatian audien. ${ }^{10}$

Tujuan penelitian ini adalah untuk mengetahui pengaruh media promosi kesehatan tentang ASI eksklusif terhadap peningkatan pengetahuan ibu.

\section{METODE}

Penelitian ini merupakan eksperimen semu (quasi-experimental) dengan rancangan pretestposttest group design. ${ }^{11}$ Tempat penelitian di wilayah kerja puskesmas Lubuk Begalung Padang. Waktu penelitian dilakukan selama satu bulan.

Populasi penelitian ini adalah semua ibu hamil yang ada di wilayah kerja puskesmas Lubuk Begalung Padang dengan jumlah subject sebanyak 42 orang ibu hamil yang dibagi dua menjadi 21 orang ibu hamil untuk kelompok perlakuan I (media leaflet) dan 21 orang ibu hamil untuk kelompok perlakuan II (media film).

Variabel independen adalah media leaflet dan film, sedangkan variabel dependen adalah pengetahuan. Setiap kelompok perlakuan akan diukur perbedaan pengetahuannya sebelum dan sesudah diberikan media dengan uji Wilcoxon Signed Rank Test dan kemudian dilakukan uji Mann-Whitney untuk membandingkan media yang digunakan pada kedua kelompok perlakuan yang menggunakan program SPSSdengan $\alpha=0,05$. 
HASIL

\section{Karakteristik Responden}

Tabel 1. Distribusi Frekwensi Responden Berdasarkan Karakteristik

\begin{tabular}{|c|c|c|c|c|}
\hline \multirow{3}{*}{ Karakteristik } & \multicolumn{4}{|c|}{ Kelompok } \\
\hline & \multicolumn{2}{|c|}{ Leaflet } & \multicolumn{2}{|c|}{ Film } \\
\hline & $n$ & $\%$ & $\mathbf{n}$ & $\%$ \\
\hline \multicolumn{5}{|l|}{ Umur } \\
\hline$<20->35 \mathrm{tn}$ & 8 & 38,1 & 4 & 18 \\
\hline $20-35$ th & 13 & 61,9 & 17 & 81 \\
\hline \multicolumn{5}{|l|}{ Tk Pendidikan } \\
\hline D III/ PT & 2 & 9,5 & 2 & 9,5 \\
\hline SLTA & 10 & 47,6 & 11 & 52,4 \\
\hline SLTP & 5 & 23,8 & 6 & 28,6 \\
\hline SD & 4 & 19 & 2 & 9,5 \\
\hline \multicolumn{5}{|l|}{ Pekerjaan } \\
\hline PNS/ Swasta & 3 & 14,3 & 2 & 9,5 \\
\hline Wiraswasta/ & 5 & 23,8 & 4 & 19 \\
\hline \multicolumn{5}{|l|}{ Pedagang } \\
\hline Tani/ Buruh & 2 & 9,5 & 1 & 4,8 \\
\hline Rumah Tangga & 11 & 52,4 & 14 & 66,7 \\
\hline \multicolumn{5}{|l|}{ Frekwensi } \\
\hline \multicolumn{5}{|l|}{ Kehamilan } \\
\hline I & 8 & 38,1 & 10 & 47,6 \\
\hline II & 5 & 23,8 & 5 & 23,8 \\
\hline III & 6 & 28,6 & 2 & 9,5 \\
\hline IV & 2 & 9,5 & 3 & 14,3 \\
\hline V & - & - & 1 & 4,8 \\
\hline
\end{tabular}

Hasil penelitian menunjukkan bahwa sebagian besar ibu hamil berumur 20-35 tahun dimana kelompok media leaflet sebanyak $61,9 \%$ dan media film $81 \%$. Tingkat pendidikan responden sebagian besar adalah SLTA baik kelompok media leaflet $(47,6 \%)$ maupun kelompok media film (52,4\%). Sebagian besar pekerjaan responden adalah sebagai ibu rumah tangga yaitu 52,4\% (kelompok media leaflet) dan 66,7\% (kelompok media film). Responden sebagian besar dengan kehamilan I 38,1\% (kelompok media leaflet) dan 47,6\% (kelompok media film).
Perbedaan Rerata Nilai Pengetahuan Responden tentang ASI Eksklusif Sebelum dan Sesudah Diberikan Promosi Kesehatan dengan Media Leaflet

Tabel 2. Perbedaan Rerata Nilai Pengetahuan Responden tentang ASI Eksklusif Sebelum dan Sesudah Diberikan Promosi Kesehatan dengan Media Leaflet

\begin{tabular}{rcc}
\hline Pengetahuan & Mean \pm SD & Nilai $\mathbf{p}$ \\
\hline $\begin{array}{l}\text { Sebelum diberikan } \\
\text { promosi kesehatan }\end{array}$ & $8,71 \pm 3.24$ & 0,001 \\
Sesudah diberikan & $11,52 \pm 2,65$ & \\
promosi kesehatan & & \\
\hline
\end{tabular}

Berdasarkan Tabel 2 dapat diketahui bahwa bahwa rerata pengetahuan responden sebelum diberikan promosi kesehatan dengan media leaflet adalah 8,71 sedangkan rerata setelah diberikan media leaflet yaitu 11,52 dengan nilai $p=0,001$.

Perbedaan Rerata Nilai Pengetahuan Responden tentang ASI Eksklusif Sebelum dan Sesudah Diberikan Promosi Kesehatan dengan Media Film

Tabel 3. Perbedaan Re-rata Nilai Pengetahuan Responden tentang ASI Eksklusif Sebelum dan Sesudah Diberikan Promosi Kesehatan dengan Media Film

\begin{tabular}{ccc}
\hline Pengetahuan & Mean \pm SD & Nilai $\mathbf{p}$ \\
\hline $\begin{array}{l}\text { Sebelum diberikan } \\
\text { promosi kesehatan }\end{array}$ & $7,90 \pm 2,25$ & 0,001 \\
Sesudah diberikan & $13,19 \pm 1,12$ & \\
promosi kesehatan & & \\
\hline
\end{tabular}

Berdasarkan Tabel 3 dapat diketahui bahwa rerata pengetahuan responden sebelum diberikan promosi kesehatan menggunakan media film adalah 7,90 sedangkan rerata sesudahnya meningkat menjadi 13,19 dengan nilai $p=0,001$. 
Perbedaan Rerata Selisih Nilai Pengetahuan

Responden tentang ASI Eksklusif Sesudah Diberikan Promosi Kesehatan Menurut Media

Tabel 4. Perbedaan Rerata Selisih Nilai Pengetahuan tentang ASI Eksklusif Responden Sesudah Diberikan Promosi Kesehatan Berdasarkan Media

\begin{tabular}{lcc}
\hline \multicolumn{1}{c}{ Media } & Mean \pm SD & Nilai $\mathbf{p}$ \\
\hline Leaflet & $2,81 \pm 2,20$ & 0,001 \\
Film & $5,29 \pm 2,19$ & \\
\hline
\end{tabular}

Berdasarkan Tabel 4 didapatkan rerata selisih nilai pengetahuan responden yang diberikan promosi kesehatan dengan media leaflet yaitu sebesar 2,81 , sedangkan media film adalah 5,29 dengan nilai $p=0,001$.

\section{PEMBAHASAN}

\section{Karakteristik Responden}

Menurut Wiknjosastro, usia 20-35 tahun adalah usia yang paling tepat bagi seorang wanita untuk hamil, karena tubuh berada dalam keadaan yang sehat dan aman untuk hamil juga melahirkan. Hal yang mendasari pembagian umur tersebut berdasarkan faktor resiko yang dialami seorang wanita.Umur responden terbanyak pada kelompok media leaflet adalah pada kelompok usia 20-35 tahun $(61,9 \%)$. Pada kelompok media film umur responden terbanyak juga berada pada kelompok usia 20-35 tahun $(81 \%)^{12}$

Semakin tinggi pendidikan seseorang makin mudah pula mereka menerima informasi, yang pada akhirnya semakin banyak pula pengetahuan yang dimilikinya. Pendidikan berperan dalam proses pengembangan diri manusia, sehingga erat kaitannya dengan reaksi serta pembuatan keputusan terhadap suatu hal. ${ }^{13}$ Tingkat pendidikan responden terbanyak adalah pada kategori pendidikan menengah atau SLTA $(47,6 \%)$ pada kelompok media leaflet dan $52,4 \%$ pada kelompok media film. Masih ada responden yang berpendidikan SD (pendidikan dasar) yaitu $19 \%$ pada kelompok media leaflet dan 9,5\% pada kelompok media film.

Responden dikatakan bekerja adalah apabila melakukan aktifitas ke luar rumah ataupun di dalam rumah untuk mendapatkan uang kecuali pekerjaan rumah tangga. Status pekerjaan akan berpengaruh terhadap pengetahuan seseorang yang akhirnya akan berdampak terhadap pemberian ASI secara eksklusif. Lebih dari separoh $(52,4 \%)$ responden pada kelompok media leaflet tidak bekerja atau sebagai ibu rumah tangga dan juga lebih separoh $(66,7 \%)$ pada kelompok media film

Paritas adalah jumlah anak yang dilahirkan, termasuk yang meninggal dengan usia kehamilan $>36$ minggu. Paritas 1-3 merupakan paritas yang paling aman bagi kesehatan ibu maupun janin dalam kandungan. $^{12}$ Pada kelompok media leaflet $38,1 \%$ responden dengan kehamilan pertama, 23,1\% kehamilan kedua, 23,8\% kehamilan ketiga. Dalam penelitian ini juga ditemukan $9,5 \%$ responden dengan kehamilan ke empat. Pada kelompok media film terdapat $47,6 \%$ kehamilan pertama, $23,8 \%$ kehamilan ke dua, 9,5 kehamilan ke tiga dan juga masih ada $14,3 \%$ dengan kehamilan keempat serta $4,8 \%$ kehamilan kelima.

\section{Perbedaan Rerata Nilai Pengetahuan Responden tentang ASI Eksklusif Sebelum dan Sesudah Diberikan Promosi Kesehatan dengan Media Leaflet}

Berdasarkan hasil penelitian dengan menggunakan uji wilcoxcon diketahui bahwa rerata pengetahuan responden meningkat setelah diberikan media leaflet dengan $p=0,001$. Leaflet merupakan media yang sarat dengan tampilan visual gambar, sehingga melibatkan indera penglihatan responden, apa yang dilihat responden melibatkan $30 \%$ dari indera penglihatan. ${ }^{14}$

Berdasarkan karakteristik responden, juga ditemukan bahwa responden dengan pendidikan SD justru lebih banyak menjawab dengan benar pada saat pretest (93,3\%) daripada responden dengan pendidikan D-III/PT yaitu hanya 33,3\%. Hal ini berarti tidak semua yang berpendidikan tinggi memiliki pengetahuan tinggi pula. Dilihat dari pekerjaannya, responden yang berpendidikan SD berwiraswasta sementara yang pendidikan D-III/PT hanya sebagai ibu rumah tangga. Menurut Notoatmodjo, selain pendidikan, pekerjaan juga mempengaruhi tingkat pengetahuan seseorang. Dengan bekerja orang akan banyak mendapatkan informasi dan juga pengalaman tentang banyak hal yang bermanfaat baginya. ${ }^{15}$ 
Perbedaan Rerata Nilai Pengetahuan Responden tentang ASI Eksklusif Sebelum dan Sesudah Diberikan Promosi Kesehatan dengan Media Film

Berdasarkan hasil penelitian dengan menggunakan uji wilcoxcon diketahui bahwa rerata pengetahuan responden meningkat setelah diberikan media film dengan $p=0,001$. Berdasarkan karakteristik responden juga ditemukan bahwa ternyata responden dengan pendidikan SLTA dan bekerja sebagai PNS/Swasta justru sedikit menjawab dengan benar pertanyaan pada saat pretest yaitu 46,7\%, dibandingkan dengan responden dengan pendidikan SLTP dan sebagai ibu rumah tangga yaitu 73,3\%. Salah satu model promosi kesehatan yang kreatif dan inovatif adalah media film dimana dengan penayangan sebuah film, materi yang disampaikan menjadi tidak monoton dan tidak membosankan sehingga membuat terjadinya transfer of knowledge menjadi lebih baik. ${ }^{14}$

\section{Perbedaan Rerata Selisih Nilai Pengetahuan Responden tentang ASI Eksklusif Sesudah Diberikan Promosi Kesehatan Menurut Media}

Berdasarkan hasil penelitian dengan menggunakan uji Mann-Whitney diketahui bahwa bahwa responden yang diberikan promosi kesehatan dengan media film memiliki rerata peningkatan pengetahuan yang lebih tinggi dari pada responden yang diberikan promosi kesehatan dibanding media leaflet dengan $p=0,001$. Menurut Mulyana tingkat keberhasilan penyampaian makna dari suatu pesan yang disampaikan juga dipengaruhi oleh metode dan media yang tepat. Metode dan media dengan kemasan serta kalimat yang menarik akan mempengaruhi dalam penyampaian pesan tersebut. Hal ini menunjukkan bahwa media film lebih efektif untuk sebuah proses perubahan, membuat konsep yang lebih abstrak menjadi konkrit dan dapat menjelaskan konsep yang sulit, mendorong motivasi belajar sehingga mudah dimengerti dibandingkan media leaflet yang hanya menyajikan gambar dan tulisan saja. Selain itu kelebihan film sebagai media promosi kesehatan dapat merangsang pikiran, perasaan, perhatian, dan kemauan sehingga dapat mendorong terjadinya perubahan pengetahuan. ${ }^{16}$

\section{KESIMPULAN}

Promosi kesehatan menggunakan media film lebih efektif dalam meningkatkan pengetahuan dibanding menggunakan media leaflet.

\section{UCAPAN TERIMA KASIH}

Peneliti mengucapkan terima kasih kepada dr. Desmiwarti, Sp.OG(K) dan Dr. Dra. Emi Nurjasmi, M.Kes sebagai pembimbing atas masukan dan arahannya dalam menyelesaikan tesis ini.

\section{DAFTAR PUSTAKA}

1. Needlman RD. Growth and development. Dalam: Behrman, Kliegman, Jenson, editor (penyunting). Nelson Textbook of Pediatrics. Edisi ke-17. USA: Saunders; 2004. hlm. 23-44.

2. Badan Litbangkes. Riset kesehatan dasar (Riskesdas) 2010. Jakarta; 2010.

3. BPS, BKKBN, Kemenkes 2012. Survei demogravi dan kesehatan Indonesia. Jakarta; 2012.

4. Dinkes Sumatera Barat. Profil kesehatan provinsi Sumatera Barat 2011. Sumbar; 2012.

5. Dinkes Sumatera Barat. Profil kesehatan provinsi Sumatera Barat 2012. Sumbar; 2013.

6. Dinkes Kota Padang. Profil kesehatan kota Padang tahun 2011. Padang; 2012.

7. Dinkes Kota Padang. Profil kesehatan kota Padang tahun 2012. Padang; 2013

8. Notoatmodjo S. Promosi kesehatan teori dan aplikasi. Jakarta: Rineka Cipta; 2010.

9. Emilia RC. Pengaruh penyuluhan ASI eksklusif terhadap pengetahuan dan sikap ibu hamil di Mukim Laure-E kecamatan Simeulue Tengah Kabupaten Simeulue (NAD). Medan: Fakultas Kesehatan Masyarakat Universitas Sumatera Utara; 2008

10. Notoatmodjo S. Pendidikan kesehatan dan ilmu perilaku kesehatan. Jakarta: Rineka Cipta; 1993.

11. Sastroasmoro S, Ismael S. Dasar-dasar metodologi penelitian klinis. Jakarta: Sagung Seto; 2011.

12. WiknjosastroH. Ilmu kebidanan. Jakarta: Yayasan Bina Pustaka; 2007. 
13. Mubarak WI, Chayatin N, Rozikin K,Suoradi. Promosi kesehatan; sebuah pengantar proses belajar mengajar dalam pendidikan. Yogyakarta: Garaha IImu; 2007.

14. Departemen Kesehatan RI. Pedoman pengelolaan promosi kesehatan dalam pencapaian PHBS. Jakarta: Pusat Promosi Kesehatan; 2008.

15. Notoatmodjo S. Ilmu perilaku kesehatan. Jakarta: Rineka Cipta; 2010.

16. Mulyana D. Ilmu komunikasi. Bandung: Rosdakarya; 2005. 